\title{
Influence of trawl type on the composition and diversity of deep benthopelagic fish and decapod assemblages off the Catalan coasts (western Mediterranean)
}

\author{
JOAN E. CARTES ${ }^{1}$, FRANCESC MAYNOU ${ }^{1}$, DOMÈNEC LLORIS ${ }^{1}$, \\ LUIS GIL DE SOLA ${ }^{2}$ and MARIANO GARCIA ${ }^{3}$ \\ ${ }^{1}$ Institut de Ciències del Mar (CMIMA-CSIC), Psg. Marítim de la Barceloneta 37-49, Barcelona. \\ E-mail: jcartes@icm.csic.es \\ ${ }^{2}$ Instituto Español de Oceanografía (IEO), Muelle Pesquero s/n, 29640 Fuengirola \\ ${ }^{3}$ Instituto Español de Oceanografía (IEO), Servicios Centrales, Corazón de María, 8, 28002 Madrid.
}

\begin{abstract}
SUMMARY: A series of 57 (600-750 m) and $32(1184-1320 \mathrm{~m})$ hauls were compiled to compare data from four trawl types in analyses of the species composition and diversity of deep benthopelagic fish and decapods off the Catalonian coasts (western Mediterranean). Two 1-warp trawls (OTSB-14 and MTS-25) and two 2-warp trawls (a commercial trawl [CT] and a GOC73) were used, from hauls performed between 1988 and 2007 were compiled. At 600-750 m the OTSB-14 hauls were separated in multi-dimensional scaling (MDS) from hauls performed with MTS-25, CT, and GOC73. Ordination of hauls along DIM1 of MDS was significantly correlated (Spearman's $r$ ) with mesh size at codend, bridle length, and vertical opening of trawls. When CT and GOC73 were compared with MTS-25, the most dissimilar species were Aristeus antennatus, Galeus melastomus and Trachyrhynchus scabrus. A particular case was A. antennatus, with a significantly higher abundance in MTS-25 catches than the rest of the trawls. At 1200-1300 m the OTSB-14 and MTS-25 hauls were segregated in MDS analysis. DIM2 was correlated with the sampling period (month), indicating a temporal effect on haul composition. At 1200$1300 \mathrm{~m}$ the main dissimilarities between OTSB-14 and MTS-25 were marked by Alepocephalus rostratus and A. antennatus (caught with MTS-25), and by Cataetyx alleni, the Notacanthidae Notacanthus bonapartei and Polyacanthonotus rissoanus, and Plesionika acanthonotus (caught with OTSB-14). As a conclusion, OTSB-14 showed a significantly higher abundance in catches than MTS-25, CT and GOC73, and a higher $S$ (number of species) and $J$ (equitability) than MTS-25. On the lower slope seasonality influenced trawl comparisons; however, it is likely that MTS-25, with higher vertical height than OTSB14 , caught the benthopelagic fish $A$. rostratus more efficiently, explaining the higher biomass from MTS- 25 there. MTS-25 positively selected $A$. antennatus, in parallel to a negative catchability for other species.
\end{abstract}

Keywords: deep sea, trawl comparison, diversity, decapod crustaceans, fishes, Aristeus antennatus, OTSB.

RESUMEN: INFLUENCIA DEL TIPO DE ARTE DE ARRATRE UTILIZADO EN LA COMPOSICIÓN Y LA DIVERSIDAD DE LAS COMUNIDADES DE PECES Y CRUSTÁCEOS DECÁPOdOS BENTOPELÁGICOS DE LA COSTA CATAlANA (MEdTERRÁNEO OCCIDENTAL). - Se recopilaron datos sobre la abundancia de peces y crustáceos decápodos de un total de 57 (600-750 m) y 32 (1184-1320 m) lances de una zona concreta de las costas de Cataluña (Mediterráneo Occidental) para comparar la composición y diversidad de estas comunidades en función de la utilización de cuatro tipos distintos de artes de arrastre bentónicos. Dos tipos de arte de arrastre de 1 cable (OTSB-14 y MTS-25) y dos más de 2 cables (un arte comercial, CT y un GOC73) fueron utilizados en lances efectuados entre 1988 y 2007. A 600-750 m los lances efectuados con el OTSB-14 se segregaron (en un análisis MDS) de los lances realizados con el MTS-25, el CT, y el GOC73. La ordenación de los lances a lo largo del primer eje (DIM1) del MDS presentó una correlación significativa ( $r$ de Spearman) con la luz de malla en el sobrecopo, con la longitud de las malletas de los artes y con sus aberturas verticales. Al comparar los modelos CT y GOC73 con el MTS-25 las especies con mayor disimilaridad fueron Aristeus antennatus, Galeus melastomus y Trachyrhynchus scabrus. A. antennatus constituyó un caso particular con una densidad significativamente mayor en los lances de MTS-25 en comparación con el resto de artes utilizados. A 1200-1300 m los lances de OTSB-14 y de MTS-25 se segregaron en los análisis MDS. El segundo eje (DIM2) se correlacionó con el perido de muestreo (mes), indicando un efecto estacional en la composición de especies. A $1200-1300$ 


\begin{abstract}
m la principal disimilaridad entre la composición del OTSB-14 y del MTS-25 vino marcada por Alepocephalus rostratus y por A. antennatus (capturados preferentemente con el MTS-25) y por Cataetyx alleni, por los Notacanthidae Notacanthus bonapartei y Polyacanthonotus rissoanus, y por Plesionika acanthonotus (capturados con el OTSB-14). En conclusión el OTSB-14 mostró una mayor abundancia en sus capturas que el MTS-25, el CT y el GOC73, mientras la $S$ (número de especies) y la $J$ (equitabilidad) fueron también significativamente más elevados en los lances con OTSB-14 que en los de MTS-25. En el talud inferior se encontró influencia del factor estacionalidad en la composición de peces y decápodos. Sín embargo, el MTS-25, con mayor abertura vertical que el OTSB-14, debe capturar A. rostratus de manera más eficiente dados los hábitos bentopelágicos de esta especie. Esto explica asimismo la mayor biomasa obtenida con el MTS-25 en este estrato. El MTS-25 seleccionó positivamente $A$. antennatus, coincidiendo con una capturabilidad negativa hacia otras especies.
\end{abstract}

Palabras clave: mar profundo, comparación de artes, diversidad, crustáceos decápodos, peces, Aristeus antennatus, OTSB.

\section{INTRODUCTION}

Information on the distribution of deep sea megafaunal (e.g. fish) assemblages and their diversity and abundance along depth gradients is still far from fully understood, especially considering that these aspects and their possible causes (e.g. trophic relationships) are relatively well known for only a few areas (e.g. Porcupine Seabight in the NE Atlantic, Merrett et al., 1991a, b; Mid-Atlantic Ridge, Bergstad et al., 2008). The marginal depths off the Iberian Mediterranean coasts (e.g. Balearic Basin, western Mediterranean) are among these reasonably well-known areas, and a considerable amount of information is available regarding the structure and dynamics of megafaunal-macrofaunal assemblages (Abelló and Valladares, 1988; Cartes and Sardà, 1993; Cartes et al. 1994; Stefanescu et al., 1992, 1993; Maynou and Cartes, 2000, Abelló et al., 2002), particularly trophic webs and trophic interrelationships among fishes (Macpherson, 1981; Carrassón and Cartes, 2002) and decapod crustaceans (Cartes, 1993; 1994). This work performed in the Balearic Basin has been recognised in recent reviews referring to "the active work developed by the group of Barcelona" (Tyler, 2003). Bathyal assemblages in the deep Mediterranean are dominated by two main taxa, fish and decapods, the latter well diversified with some species (e.g. Aristeus antennatus, Acanthephyra eximia, Plesionika martia) often reaching their northernmost distribution in the NW Mediterranean or at similar latitudes along NE Atlantic coasts (e.g. Cantabrian Sea, Bay of Biscay; (Lagardère, 1971; d'UdekemD'Acoz, 1999; Cartes et al., 2008). The dominance of decapods among invertebrates in the Mediterranean contrasts with the dominance of echinoderms in Atlantic waters at similar latitudes, as has been previously pointed out (Cartes and Sardà, 1993).

The deep Mediterranean is considered to be a natural laboratory (Margalef, 1985), due to its thermal $\left(13^{\circ} \mathrm{C}\right)$ and saline $(38 \mathrm{psu})$ stability below depths of only $150 \mathrm{~m}$ in the water column, though long-term changes in oceanographic conditions have also been reported (Vargas-Yáñez et al., 2009). Thus, environmental variability in areas such as the Catalan Sea slope seems low in comparison with other deep-sea areas. In addition to environmental variability, the type of collecting gear is another factor affecting the study of intra- and interannual changes in the composition and distribution of demersal bathyal assemblages (Merrett et al., 1991a; Gordon and Bergstad, 1992; Bertrand et al., 2002a). Selectivity among trawls depends on many variables, with mesh-size, mouth area, towing speed and the number of warps towing the net being the most important. Trawl comparisons have been analysed (e.g. by side-by-side trawling experiments) in shallow waters (Wilderbauer et al., 1998; Szalay and Brown, 2001), basically for fisheries purposes. Similar studies have also been performed at bathyal depths (Pearcy et al., 1982; Merrett et al., 1991a, b; Gordon and Bergstad, 1992), more focused on ecological implications relating to biomass and size vs. depth distributions (Haedrich et al., 1975; Pearcy et al., 1982).

In the Balearic Basin the first ecological studies of bathyal communities were started between 1985 and 1992 by a team of researchers at the Institut de Ciències del Mar (ICM-CSIC) of Barcelona (Rucabado et al., 1991; Stefanescu et al., 1992, 1993; Cartes, 1993; Cartes and Sardà, 1993) using a 1-warp trawl, the OTSB-14. This is a standardised trawl in the study of deep-sea megafauna (Haedrich et al., 1975; Gordon and Duncan, 1985; Merrett et al., 1991b), particularly at depths below $1000 \mathrm{~m}$, where 2-warp trawls are often difficult to use and manoeuvre. In 1991, a new 1-warp trawl system, the otter Maireta trawl system, with a headline of $25 \mathrm{~m}$ (MTS-25), was introduced in deep-water studies. MTS-25 specifications can be found in Sardà et al. (1997), who, after comparing selectivity of MTS-25 and OTSB-14 trawls based on a series of hauls performed at $1200 \mathrm{~m}$, concluded that MTS25 showed a better picture of sampled communi- 
ties, catching mobile species more efficiently. This trawl was mainly introduced to improve catches of the red shrimp Aristeus antennatus, the main target species of deep-sea fisheries in the area, incorporating features of conventional commercial gear used by red-shrimp fishermen off the coasts of Catalonia (Sardà et al., 1997). Other sources of ecological information have been obtained from the use of Agassiz trawls (Abelló and Valladares, 1988), commercial trawlers (Abelló et al., 1988), and monitoring studies performed within the framework of MEDITS-Spain cruises (see Bertrand et al., 2002b; Cartes et al., 2002). MEDITS cruises have been performed along the Spanish coasts yearly in spring (May-June) since 1994, operating to ca. $800 \mathrm{~m}$ depth under the coordination of the Instituto Español de Oceanografía (IEO) As in the case of commercial trawlers, MEDITS cruises used a GOC73, a 2-warp system with the general design of a conventional commercial otter trawl (Bertrand et al., 2002a, Fanelli et al., 2007).

The aim of this study was to establish a comparison among trawls commonly used in studies on megabenthos in the deep, western Mediterranean in terms of: 1) species composition; 2) abundance/ biomass; 3) species richness/diversity. We further discuss the biases introduced by each trawl in ecological aspects, such as zonation patterns and species distributions, and in the study of megabenthic biodiversity in bathyal habitats.

\section{MATERIALS AND METHODS}

\section{The sampling area}

We chose for our comparative study the area of the Catalonian coasts between Barcelona and the Ebro Delta, which has been the subject of many studies over the last 20 years. These sites are not under the direct influence of upwelling processes (local winds blowing in the Gulf of Lyons) (Fig. 1) and associated geological features (e.g. advective fluxes above large canyon: Palanques et al., 2005). To remove the effect of depth gradients on assemblages, we compared hauls performed in two fixed bathymetric strata: 1) the mid-slope between 600 and $750 \mathrm{~m}$, depths commonly worked by red-shrimp trawlers (Maynou, 2008); and 2) the lower slope between 1184 and $1320 \mathrm{~m}$, depths which are free of any trawling activity.

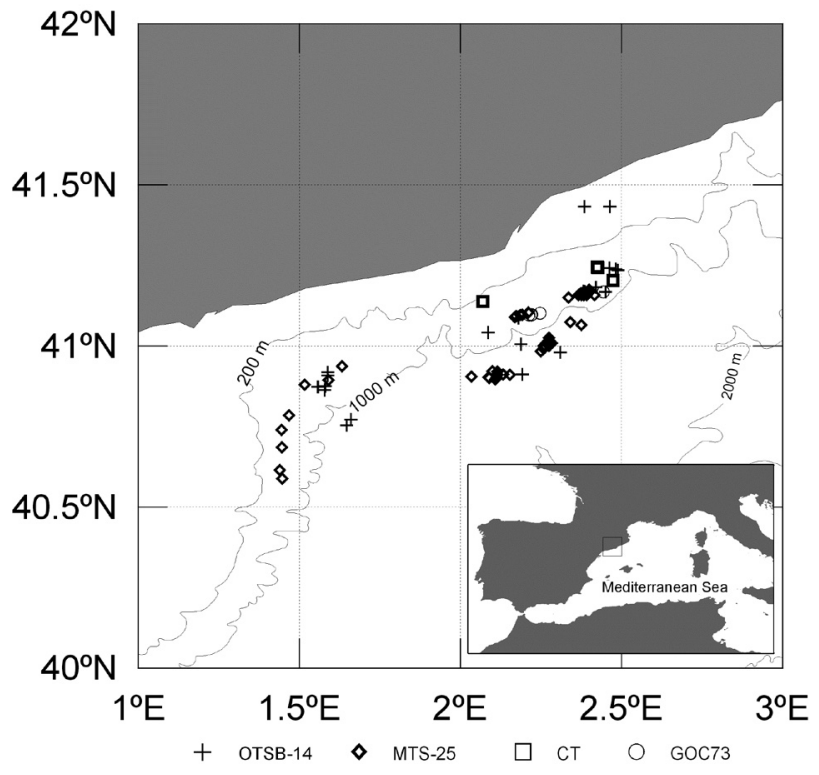

FIG. 1. - Map of the study area between Barcelona and Tarragona off the Catalan coasts.

The features of the trawls used are listed in Table 1. Together with the two 1-warp trawls used by ICMCSIC teams (OTSB-14, MTS-25), and the GOC73 used by IEO on MEDITS cruises, we introduce data from a conventional trawler, the FV Stella Maris III operating in the harbour of Barcelona. The main differences among trawls were in the mesh size at the codend (6 to $40 \mathrm{~mm}$ ), the length of bridles ( 8 to 150 $\mathrm{m}$ ), and the vertical height or opening (1.2 to $3 \mathrm{~m}$ ) (Table 1).

All hauls performed between 600 and $750 \mathrm{~m}$ and between 1184 and $1320 \mathrm{~m}$, comprising a total of 57 hauls at $600-750 \mathrm{~m}$ and 32 hauls at $1184-1320 \mathrm{~m}$, were selected for analysis. Hauls at 600-750 m were taken with four different trawls; on the lower slope only the two 1-warp models were used (OTSB14 and MTS-25) (details in Table 1). Hauls came from cruises between 1988 and 1994 (BATIMAR, SPERMA, ZONAP, GEODELTA) and in 2007 (BIOMARE) using OTSB-14, between 1991 and 1995 (RETRO, BATMAN) using MTS-25, and between 2002 and 2007 (MEDITS-IEO). Commercial trawls were part of BIOMARE samplings in 2007.

\section{Data analysis}

Fish and decapods were counted and weighed by species and classified to species level in all cases both on board and in the laboratory.

Abundance and biomass ( $\mathrm{g}$ wet weight/ha) were calculated by swept area after raw numbers (total in- 
TABLE 1. - Main comparative characteristics of the four trawls used in the study area.

\begin{tabular}{|c|c|c|c|c|}
\hline & OTSB-14 & MTS-25 & $\mathrm{CT}$ & GOC73 \\
\hline Vessel & $\begin{array}{l}R / V \text { García del Cid } \\
38 \mathrm{~m}, 1500 \mathrm{HP}\end{array}$ & $\begin{array}{c}R / V \text { García del Cid } \\
38 \mathrm{~m}, 1500 \mathrm{HP}\end{array}$ & F/V Stella Maris & $\begin{array}{c}R / V \text { Cornide Saavedra } \\
66.7 \mathrm{~m}, 1651 \mathrm{HP}\end{array}$ \\
\hline No. samples taken & 16 & 30 & 6 & 5 \\
\hline Year range & 1988/1992 - 2007 & $1991 / 1995$ & 2007 & $2002-2007$ \\
\hline Months & Fe-Ap/May-Jun/Jul-Oc & Mar-Ap-Jun/Jul-De & Fe-Ap-May-Jun/Jul-De & May-Jun \\
\hline Area covered (ha) & $2.8-5.2$ & $6.1-13.1$ & $12.1-20.4$ & $5.5-13.2$ \\
\hline No. towing warps & 1 & 1 & 2 & 2 \\
\hline Headline length (m) & 14 & 25 & 50 & 35.7 \\
\hline Bridle length $(\mathrm{m})$ & 8 & 25 & 150 & 30 \\
\hline Wing mesh size $(\mathrm{mm})$ & 44 & 80 (stretched) & - & 140 (stretched) \\
\hline Codend mesh size $(\mathrm{mm})$ & 6 & 10 (stretched $)$ & 40 & 20 (stretched) \\
\hline Horizontal length $(\mathrm{m})$ & $6.7-7.2$ & 13.5 & 25 & 18 \\
\hline Vertical height $(\mathrm{m})$ & 1.2 & 2 & 3 & 2.7 \\
\hline Median towing speed (knots) & $2.6-2.7$ & $2.6-2.8$ & $2.4-2.5$ & $2.8-2.9$ \\
\hline
\end{tabular}

dividuals collected per haul) had been standardised to individuals per hectare. Horizontal length (m) recorded by SCANMAR devices mounted on wing trawls, median towing speed (knots) and haul duration (h) were used to calculate swept area.

Multidimensional scaling (MDS) was performed on matrices of data similarities. Two distances were used for the middle slope, the quantitative Bray-Curtis distance after log-transformation of data (Clarke and Warwick, 1995), and the non-parametric Spearman's correlation coefficient, a rank-based measure. Bray-Curtis was the only distance used for the lower slope data, because both measures showed basically the same trends. Fishes and decapods were analysed together, while non-arthropod invertebrates were excluded from analyses because trawling is not a suitable method for quantifying epibenthic and infaunal invertebrates. As a consequence, variations found in epifaunal-infaunal catches cannot be due only to natural variations, but depend on the unpredictable behaviour of trawls collecting these non-swimming, often buried, species. PERMANOVA analyses (one factor, trawls; 999 permutations) were performed on a fish and decapod resemblance matrix (Bray-Curtis distance) to test the significance of groups formed in MDS analyses. SIMPER was performed to establish the contribution of each species to dissimilarities between the types of trawl. Factors (trawls) were the four types of trawl employed (CT, OTSB-14, MTS25, GOC73).

Spearman's correlations were calculated between MDS dimensions and a number of variables likely a priori to influence the species composition per trawl. The following variables were considered: i) Technical variables: mesh size at codend, trawl height (vertical opening) and bridle length (see Table 1)

ii) Natural variables: latitude (LAT) and longitude (LONG) to define the fishing grounds or areas, time of the day (h, GMT), intrannuality (month) and interannuality (year) of samples. Intrannuality of surveys was distributed as follows: BATHOS (JuneJuly, October 1988), SPERMA (October 1989), ZONAP (May 1992), GEODELTA (May 1994), RETRO (April-December 1991, March-July 1992), BATMAN (March 1994, June 1995) and BIOMARE (January 2006 to February, April-May, June-July and October 2007). A rank order was assigned per month as a function of increasing duration of daylight at the latitude studied (e.g. 1 for December, 12 for June). MEDITS were performed between 2002 and 2007, always in May-June.

iii) Measures of species diversity: number of species (N), Shannon index (H') and evenness (J).

Differences in biomass per trawl were tested by 1-way ANOVA (after log-transformation of data) for total biomass and for the main dominant species of fishes and decapods. Mean weight per haul (biomass/number) was calculated for key species having the greatest contribution to dissimilarities (e.g. Aristeus antennatus; Alepocephalus rostratus), and differences among trawls were tested by 1-way ANOVA.

Measures of diversity ( $H$, Shannon-Weaver index), evenness ( $J$, Pielou) and species richness $(S)$ per haul were calculated. Differences of mean $S$, $H$ and $J$ were tested among gear types by 1 -way ANOVA. We performed the Wilcoxon paired- 

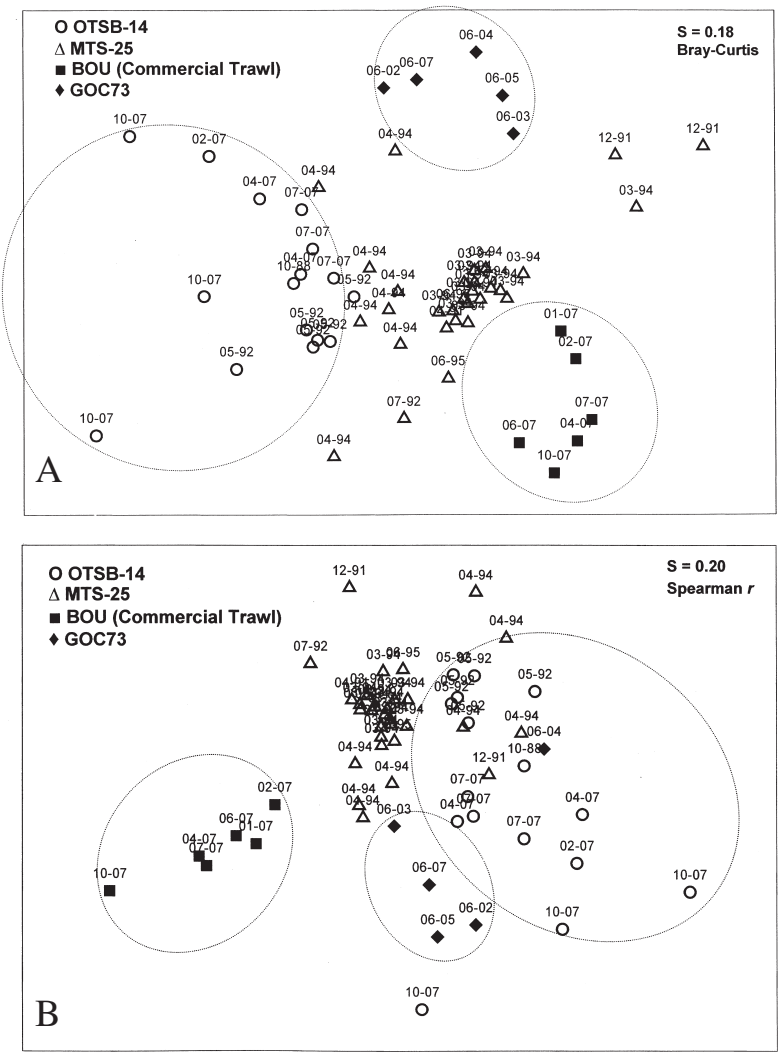

FIG. 2. - MDS (multi-dimensional scaling) analysis for fish and decapods collected with four bottom trawls at $600-750 \mathrm{~m}$. A, BrayCurtis distance; B, nonparametric Spearman's r. Labels indicate month and year of sample.

match test to establish whether the differences between each set of pairs of species abundance per trawl were significantly different from the expected $50 \%$ of switches between trawls in the absence of significant bias. We used Mann-Whitney tests to evaluate paired comparisons of species abundance from gear to gear. All the analyses were performed using PRIMER6 \& PERMANOVA+ (Clarke and Warwick, 1995; Anderson, 2001) and STATISTICA 7.0 software.

\section{RESULTS}

\section{Species composition}

\section{0-750 m depth range}

Based both on Bray-Curtis and on Spearman's $r$ distances, MDS showed similar aggregations of hauls as a function of the trawl type (Fig. 2A). Based on Bray-Curtis, the OTSB-14 hauls (on the left side of the plot) were separated from the MTS25, CT and GOC73 hauls. The six hauls performed with commercial trawls (CT) and the five GOC73 hauls were grouped together. On DIM 1 (horizontal axis), the MTS-25 hauls were on average closer to the CT hauls, and to a lesser extent to GOC73, than to the OTSB-14 hauls. Average trawl composition differed significantly between the 4 trawls used (PERMANOVA test: pseudo $F=7.44, P=0.001$; post hoc tests, $P<0.01$ between all paired comparisons). Based on Spearman's rank correlation, segregation between the OTSB-14 and GOC73 hauls was not as evident as using Bray-Curtis; GOC73 hauls occupied an intermediate position between the OTSB-14 and MTS-25 hauls in MDS. CT hauls were clearly aggregated and separated from the other hauls (Fig. 2B).

\section{0-1300 m depth range}

The OTSB-14 and MTS-25 hauls were clearly segregated (significantly different composition) in the MDS plot (Fig. 3) performed on the Bray-Curtis distance. (PERMANOVA test: pseudo $F=4.75$, $P=0.001)$.

\section{Abundance, biomass and diversity}

$600-750 m$

A 1-way ANOVA performed on total abundance of megafauna after data standardisation to area swept (ind./ha) showed significant changes in abundances as a function of trawl type $(F=5.93, P=0.001)$. Abundance of fauna caught with OTSB-14 was sig-

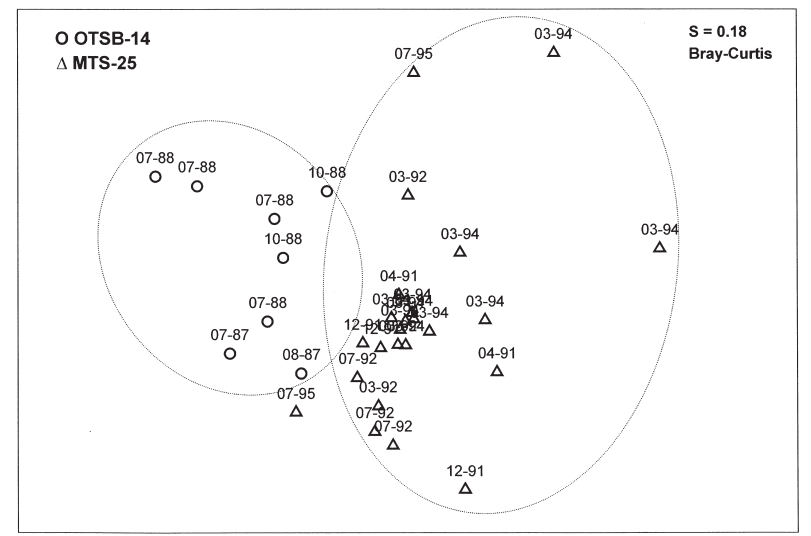

FIG. 3. - MDS (multi-dimensional scaling; Bray-Curtis distance) analysis for fish and decapods collected with the two 1-warp bottom trawls at 1150-1350 m. Labels indicate month and year of sample. 
TABLE 2. - 1-way ANOVA and t-test results at 600-750 $\mathrm{m}$ and at 1200-1350 $\mathrm{m}$ with paired post-hoc comparisons (Scheffé) for the shallower stratum. $N$, species richness; $H^{\prime}$, diversity, Shannon's index; $J$, evenness; $D$, density; $B$, biomass, $n$, number of hauls.

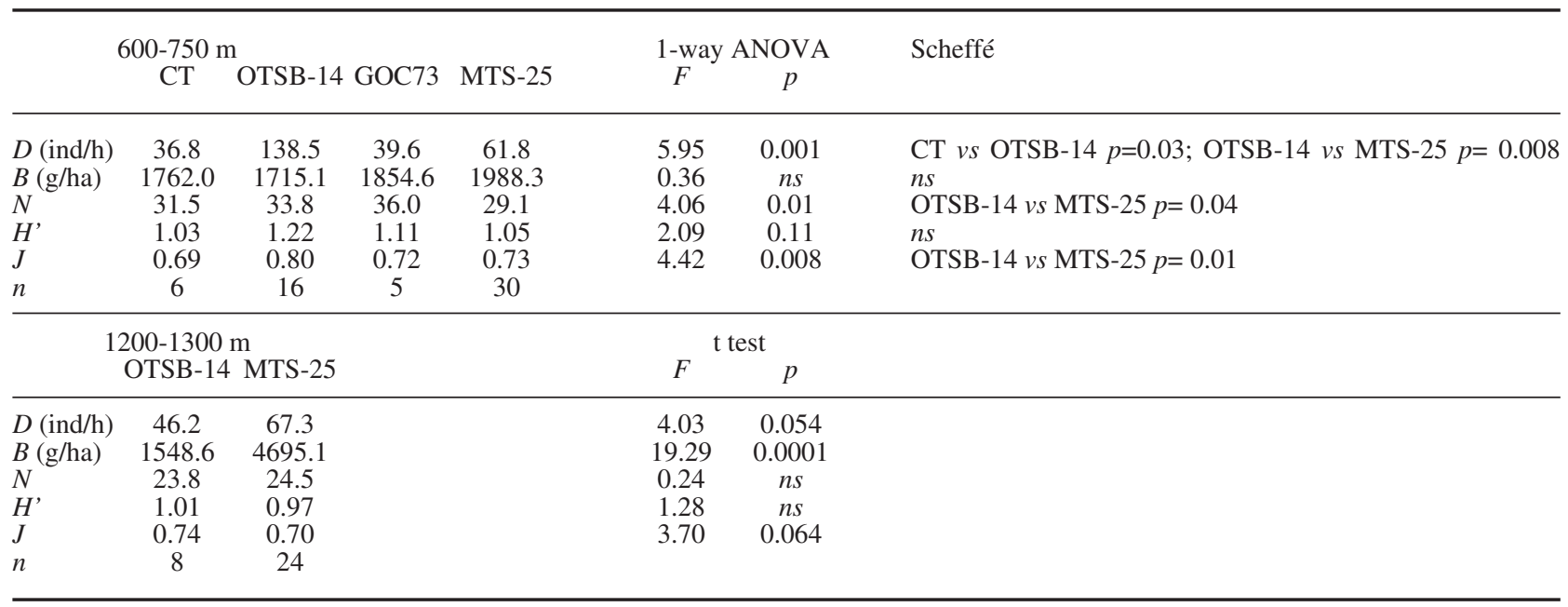

nificantly greater than with MTS-25 (Scheffé test; $P=0.008$ ) (Table 2). The biomass per swept area obtained with OTSB-14 was slightly less than for the other three trawls, but without any significant difference among the trawls (1-way ANOVA: $F=0.36$; $P=0.78$ ) (Table 2).

A 1-way ANOVA performed on $S$ (species richness), showed higher $S$ for OTSB-14 than for MTS25 ( $F=4.06, \quad P=0.01$; Scheffé test, $P=0.04$ ) (Table 2 ), while differences between MTS-25 and GOC73 $\mathrm{S}$ were close to the significance level. Shannon's $H^{\prime}$ diversity was also higher for OTSB-14 than for MTS-25 (Scheffé test, $P=0.013$; Table 2), while no significant differences among trawl type were obtained for Pielou's $(J)$ equitability (Table 2 ),

\section{$1200-1300 m$}

One-way ANOVA performed on $S, H^{\prime}$ and $J$ did not indicate significant differences between the MTS-25 and OTSB-14 trawls. Significant differences were not found for total density $(D)$, although $D$ in MTS-25 hauls was higher and close to statistical significance $(P=0.05)$. Biomass was significantly higher in the MTS-25 hauls (Table 2).

\section{Correlations between MDS dimensions and related variables}

$600-750 m$

Bray-Curtis MDS. Spearman's rank correlations indicated significantly positive relationships between DIM1 values from the MDS (Fig. 2) and mesh size $\left(r=0.718 ; p<10^{-6}\right)$, which is consistent with the respective positions of the CT hauls (mesh size $=40 \mathrm{~mm}$ ) and GOC73 (mesh size $=20 \mathrm{~mm}$ ) and the OTSB-14 hauls (mesh size $=6 \mathrm{~mm}$ ) on opposite sides of the plot. In parallel, we found similarly significant relationships $\left(r=0.791 ; P<10^{-6}\right)$ regarding other technical features of trawls (bridle length, opening height), with the highest trawls having the largest bridles and OTSB14 , with the lowest vertical opening and the shortest bridle, occupying opposite positions in the MDS plot (Fig. 2A). Furthermore, the trawl-characteristic variables $H^{\prime}(r=-0.384 ; p=0.003)$ and $J(r=-0.513 ; P=4$. $10^{-5}$ ) were negatively correlated with DIM1; that is, diversity was higher in the OTSB-14 hauls. Finally, DIM 1 was almost significantly correlated $(P=0.05)$ with LAT. This is because GOC73 and CT were exclusively performed off Barcelona, at the northernmost latitudes in our sampling area. The latitudinal effect was weak because these southernmost hauls (GE hauls, off the Ebro Delta) were not situated to the left along DIM1. DIM2 positions were not correlated with any variable.

Spearman's MDS. Similar results to those for Bray-Curtis were found for the rank-criterion ordination of hauls. DIM1 values were correlated with mesh size $\left(-0.557 ; P=7 \cdot 10^{-6}\right)$ and with both bridle length and opening height $\left(r=-0.634 ; P<10^{-6}\right)$, whereas $J$ again was greater in OTSB-14/GOC73 hauls $(r=0.329 ; P=0.01)$. DIM2 was weakly correlated with LONG $(P=0.05)$ and also with bridle length $\left(r=-0.540 ; P<1 \cdot 10^{-5}\right)$.

No significant correlations between year and month of sampling and DIM of MDS analyses (either for Bray Curtis and Spearman distances) were found. 
$1200-1300 m$

Bray-Curtis MDS. For the lower slope trawls, we did not test mesh size, bridle length or opening height as explanatory variables, because we had only one source of variation (MTS-25 vs. OTSB-14 trawls). Species number, $S$, was positively correlated with DIM1 (Fig. $3 ; r=0.389 ; P=0.02$, i.e. higher $S$ on average for hauls situated to the right). This does not mean, however, that $S$ was higher among MTS-25 hauls, because MTS25 and OTSB-14 hauls were clearly separated along DIM1, whereas $S$ was not significantly correlated with this axis. DIM1 was also negatively correlated with $J(r=-0.409 ; P=0.02)$.

DIM2 was correlated with month of sampling $(r=-0.356 ; P=0.04)$. Most MTS-25 hauls were in March-April, while OTSB-14 hauls were mainly performed in June-July and October. No significant correlations were found regarding the year of sampling or MDS dimensions.

\section{SIMPER results: species contribution by trawl types}

Considering only those species contributing $\geq 5 \%$ of $d$, higher similarities between species composition (less $d$ ) were found in the comparison of GOC73 vs OTSB-14 $(d=30.8 \%)$ and CT vs MTS-25 $(d=42.5 \%)$. In both cases, higher similarities were found in paired comparisons between 1- and 2-warp trawls than between the two 1-warp trawls $(d=43.1 \%)$ or the two 2-warp trawls $(d=59.0 \%)$.

\section{$600-750 m$}

When the trawls with the two largest mesh sizes at the codend (CT and GOC73) were compared with OTSB-14, the species contributing most to dissimilarities $(d)$ according to SIMPER analysis (Table 3) were small crustaceans such as Calocaris macandreae, Munida tenuimana and Sergestes arcticus.

TABLE 3. - SIMPER analysis results by depth strata and comparing (average dissimilarity) trawl by trawl. CT, commercial trawl.

\begin{tabular}{|c|c|c|c|c|c|}
\hline \multirow{2}{*}{$\begin{array}{l}\text { 600-750 m CT/OTSB-14 } \\
\text { species }\end{array}$} & \multicolumn{2}{|c|}{ Av Diss $=73.2$} & \multirow{2}{*}{$\begin{array}{l}\text { GOC73/OTSB-14 } \\
\text { species }\end{array}$} & \multicolumn{2}{|c|}{ Av Diss $=73.2$} \\
\hline & Av.Diss & $\%$ Contrib & & Av.Diss & $\%$ Contrib \\
\hline Calocaris macandreae & 7.45 & 10.17 & Calocaris macandreae & 7.31 & 10.19 \\
\hline Munida tenuimana & 6.27 & 8.56 & Plesionika martia & 5.59 & 7.79 \\
\hline Sergestes arcticus & 4.88 & 6.67 & Munida tenuimana & 4.86 & 6.78 \\
\hline Plesionika martia & 4.75 & 6.48 & Sergestes arcticus & 4.36 & 6.08 \\
\hline Plesionika acanthonotus & 4.05 & 5.53 & Plesionika acanthonotus & 3.96 & 5.52 \\
\hline Polycheles typhlops & 3.82 & 5.21 & & & \\
\hline CT/MTS-25 & \multicolumn{2}{|c|}{ Av Diss $=56.5$} & GOC73/MTS-25 & \multicolumn{2}{|c|}{ Av Diss $=73.7$} \\
\hline species & Av.Diss & $\%$ Contrib & species & Av.Diss & $\%$ Contrib \\
\hline Aristeus antennatus & 15.54 & 27.5 & Aristeus antennatus & 15.18 & 25.13 \\
\hline Nephrops norvegicus & 4.04 & 7.14 & Galeus melastomus & 4.5 & 7.45 \\
\hline Trachyrhynchus scabrus & 2.6 & 4.8 & Trachyrhynchus scabrus & 4.44 & 7.34 \\
\hline & & & Lampanyctus crocodilus & 4.17 & 6.9 \\
\hline & & & Geryon longipes & 3.53 & 5.84 \\
\hline $\mathrm{CT} / \mathrm{GOC} 73$ & \multicolumn{2}{|c|}{ Av Diss $=65.3$} & OTSB-14/MTS-25 & \multicolumn{2}{|c|}{ Av Diss $=61.0$} \\
\hline species & Av.Diss & $\%$ Contrib & species & Av.Diss & $\%$ Contrib \\
\hline Trachyrhynchus scabrus & 9.35 & 14.31 & Aristeus antennatus & 8.14 & 13.34 \\
\hline Phycis blennoides & 6.08 & 9.31 & Calocaris macandreae & 5.55 & 9.1 \\
\hline Lampanyctus crocodilus & 5.69 & 8.71 & Munida tenuimana & 5.13 & 8.4 \\
\hline Nephrops norvegicus & 5.01 & 7.67 & Sergestes arcticus & 3.88 & 6.35 \\
\hline Geryon longipes & 4.98 & 7.62 & Plesionika martia & 3.59 & 5.89 \\
\hline Galeus melastomus & 4.1 & 6.27 & & & \\
\hline 1200-1300 m OTSB-14/MTS-25 & & & & & \\
\hline species & Av.Diss & $\%$ Contrib & & & \\
\hline Alepocephalus rostratus & 3.34 & 9.21 & & & \\
\hline Trachyrhynchus scabrus & 2.1 & 5.79 & & & \\
\hline Nezumia aequalis & 2.09 & 5.78 & & & \\
\hline Bathypterois mediterraneus & 2.03 & 5.6 & & & \\
\hline Pontophilus norvegicus & 1.81 & 5 & & & \\
\hline Cataetyx alleni & 1.79 & 4.93 & & & \\
\hline Plesionika acanthonotus & 1.76 & 4.86 & & & \\
\hline Aristeus antennatus & 1.74 & 4.79 & & & \\
\hline Acanthephyra eximia & 1.59 & 4.39 & & & \\
\hline Mora moro & 1.49 & 4.1 & & & \\
\hline Polyacanthonotus rissoanus & 1.45 & 3.99 & & & \\
\hline
\end{tabular}




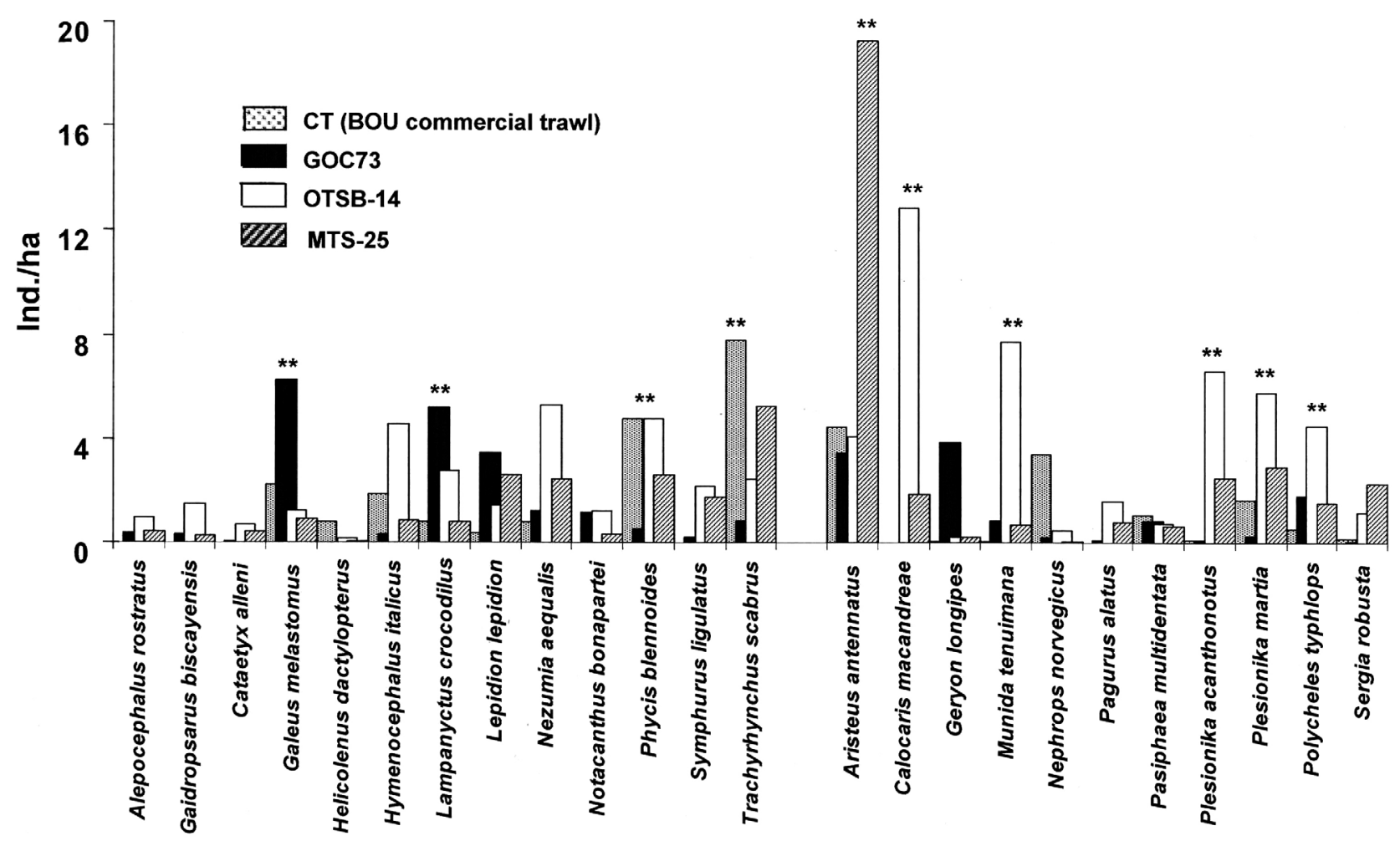

FIG. 4. - Dominant species of fishes and decapods as a function of gear at mid-slope depths $(600-750 \mathrm{~m})$. Asterisks (**) above species indicate that differences in catchability were significant among trawls.

When CT and GOC73 were compared with MTS-25, however, the most dissimilar species were not small species, but large ones such as Aristeus antennatus, Galeus melastomus and Trachyrhynchus scabrus. A particular case was Aristeus antennatus, for which $d$ was greater between MTS-25 and the large 2-warp trawls (CT and GOC73, respectively 15.2-15.7\%) than between MTS-25 and OTSB-14 (8.1\%).

\section{$1200-1300 \mathrm{~m}$}

At $1200 \mathrm{~m}$ the main dissimilarities between OTSB-14 and MTS-25 were marked by Alepocephalus rostratus and Aristeus antennatus being caught mostly with MTS-25, and by Lepidion lepidion and Munida tenuimana being mainly caught with OTSB14 (Table 3).

\section{Species-by-species abundance per trawl type}

$600-750 \mathrm{~m}$

A species-by-species, 1-way ANOVA showed significantly higher abundance of Aristeus antennatus when it was collected with an MTS-25 than with an OTSB-14 (Scheffé test; $P<0.001)$ or the CT $(P<0.05$ : (Fig. 4). Other species showed significantly different catchability depending on the trawl used. Other decapods showing such differences were Calocaris macandreae (higher catchability with OTSB-14 than with GOC73 or CT, $P<0.001$ ), Munida tenuimana (higher catchability with OTSB14 than with GOC73, $P<0.05$, and greater with MTS-25 than with CT, $P<0.001)$, Plesionika acanthonotus (higher catchability with OTSB-14 than with GOC73 or CT, $P<0.01$; higher catchability wth MTS-25 than with CT, $P<0.05)$, Plesionika martia (higher catchability with OTSB-14 than with GOC73 or MTS-25, $P<0.01$ ) and Polycheles typhlops (higher catchability with OTSB-14 than with MTS-25 or $\mathrm{CT}, P<0.01)$. In general most of these differences are attributable to the smaller mesh size of OTSB14 in comparison with the two 2-warp trawls. However, differences between OTSB-14 and MTS-25 for mid-sized species, such as Plesionika martia and Polycheles typhlops, cannot be explained by mesh-size differences alone. Among fish, Galeus melastomus showed significantly higher abundance with GOC73 than with OTSB-14 $(P>0.01)$, while MTS-25 showed lower catching efficiency than 


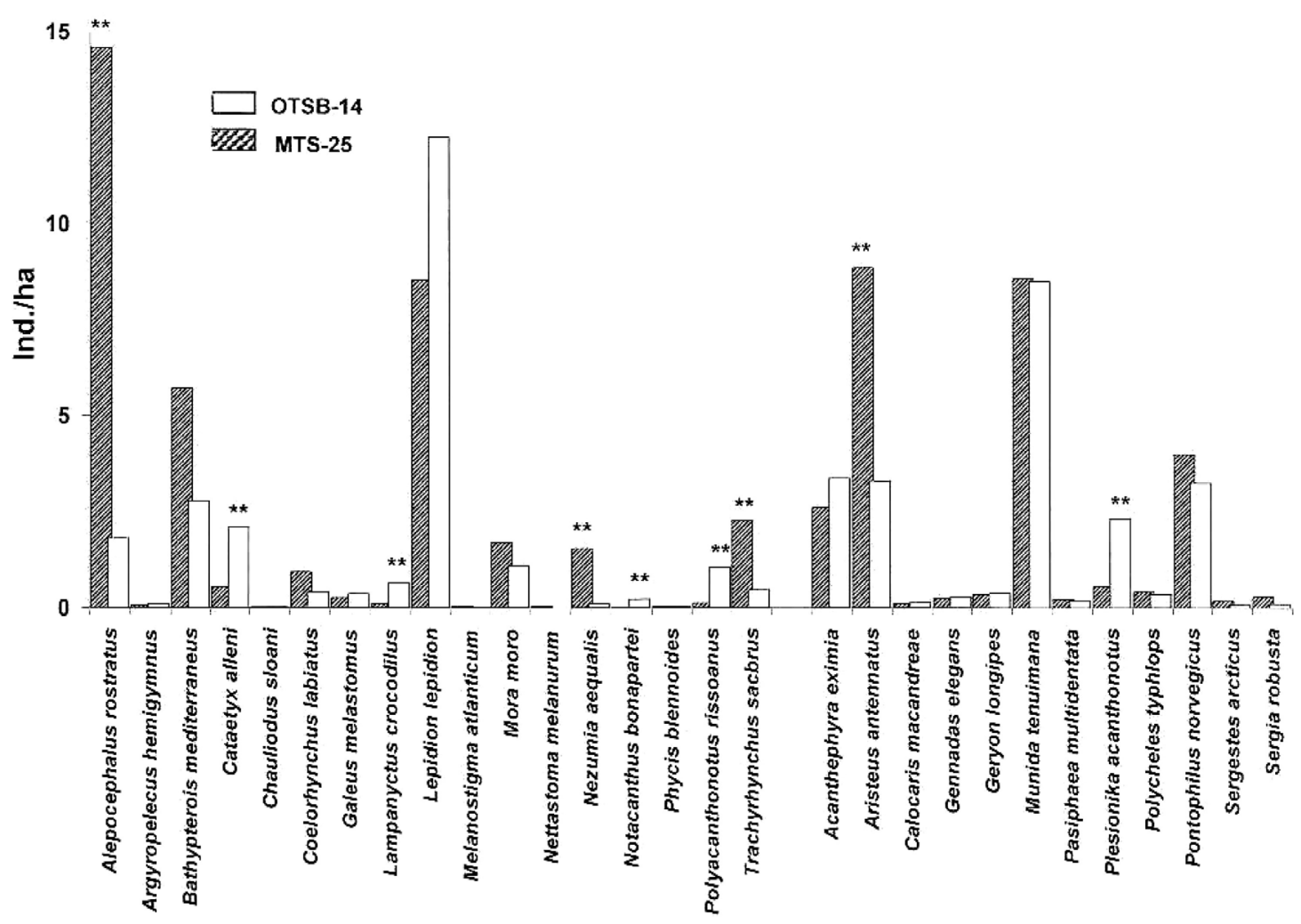

FIG. 5. - Dominant species of fishes as a function of gear at the lower slope depths (1200-1300 m). Asterisks (**) above species indicate that some differences in catchability were significant among trawls.

GOC73 $(P<0.001)$ and CT $(P<0.05)$. Lampanyctus crocodilus showed lower catchability with MTS-25 than with either OTSB-14 $(P<0.001)$ or GOC73 $(P<0.05)$. Phycis blennoides showed significantly lower catchability with GOC73 $(P<0.05)$ than with CT. Trachyrhynchus scabrus was collected in greater numbers with $\mathrm{CT}$ than with the other trawls $(P<0.01)$, and more were caught with MTS-25 than with OTSB-14 $(P<0.05)$.

Comparing catches of the two 1-warp trawls, a significant number of species showed greater abundance in the OTSB-14 hauls $(n=19)$ than in the MTS-25 hauls ( $\mathrm{n}=4$ ) (Wilcoxon paired-matched test was significantly different from the expected $50 \%$ in the absence of any significant effect, $P>0.001$ ). No significant trends were found between the two 2-warp systems.

\section{$1100-1300 m$}

Some fishes showed higher catchability with MTS-25 (Fig. 5): Alepocephalus rostratus ( $t$ test, $P<0.001)$, Nezumia aequalis $(P<0.001)$ and Trachyrhynchus scabrus $(P<0.01)$ together with Aristeus antennatus $(P<0.01)$. On the other hand, Catatetyx alleni $(P<0.001)$, Lampanyctus crocodilus $(P<0.05)$ and the notacanthids Notacanthus bonapartei and Polyacanthonotus rissoanus $(P<0.05)$ were more readily caught by the OTSB-14. The same trend was found for the shrimp Plesionika acanthonotus $(P<0.05)$. All these comparisons, however, could be biased by seasonality.

The number of species collected more effectively by MTS- 25 was not significantly different from the number collected better by OTSB-14 (Wilcoxon paired-matched test).

\section{DISCUSSION}

Our approach was based on trawl series performed in two relatively narrow depth ranges $(600-750 \mathrm{~m}$ and $1200-1300 \mathrm{~m}$ ) in a homogeneous area over a period of $c a .20 \mathrm{yrs}$. Though it was not a side-by-side trawling experiment, as performed at shelf depths (e.g. by Szalay and Brown, 2001), similar approaches combining data from different surveys have been applied at bathyal depths (e.g. in the North Atlantic: Merrett et al., 1991a, b) due to the limitations of performing trawl and side-by-side surveys at great depths. 


\section{Natural and human-induced variability}

Previous studies on muddy, bathyal bottoms off the Iberian coasts showed significant changes in megafaunal assemblages at the spatial mesoscale (latitude: Cartes et al., 2002) with an effect of the mainland/island factor (Cartes et al., 2004). Trophic guilds of decapods and fish varied along the Spanish Mediterranean coasts from Catalonia to the Straits of Gibraltar, with a north to south increase in plankton feeders. Also, around insular areas in the Iberian Mediterranean coasts, low advective fluxes (e.g. river discharges) and the impoverishment of benthic biomass are characteristic (Cartes et al., 2004), enhancing differences between insular and mainland bathyal communities. As latitude was not correlated with species composition in our MDS analyses, we can consider the geographic area selected as homogeneous for our purpose.

Anthropogenic factors, mainly fisheries, may also influence the composition of megafaunal assemblages in the study area. The trawler fleet has moved deeper (to $c a .900 \mathrm{~m}$ ) in search of Aristeus antennatus in recent years off the Catalan coasts, though the influence of trawling on communities is nil below $900 \mathrm{~m}$ depth (Cartes et al., 2004), and the lower slope at 1200-1300 m must be considered as a pristine area. Isidella elongata, a soft-coral forming a characteristic facies in the deep Mediterranean (Pérès, 1985), which is inhabited by important commercial species (the large red-shrimps Aristeus antennatus and Aristaeomorpha foliacea), is immediately removed from fishing grounds by trawling. Habitat generated by Isidella enhances diversity of fish and especially of decapods, some of them living as epibionts on coral colonies (author's unp. data). Geodelta survey (GE) hauls were the only ones performed in pristine areas at $600-750 \mathrm{~m}$, while the rest were from fishing grounds of the red shrimp Aristeus antennatus. However, the massive occurrence of Isidella elongata colonies (author's unp. data) in GE hauls cannot influence our analyses performed only on fish and decapods (GE hauls not segregated from the rest performed on fishing grounds in MDS analyses).

Other sources of variability in deep-sea communities are related to temporality (Tyler, 1988). In the deep Mediterranean, seasonality strongly influences the dynamics of benthopelagic communities (Cartes, 1998; Cartes et al., 2008), trophic relationships and food consumption (Cartes, 1994; Madurell and
Cartes, 2005), and the biological cycles of bathyal species, both macrofauna and megafauna (Cartes and Sorbe, 1996; Fanelli and Cartes, 2008). Though seasonality $(=$ month) had no significant effect on trawls from the $600-750 \mathrm{~m}$ stratum, it significantly influenced the species composition at 1200-1300 m, so trends observed in that stratum can be biased by natural variability and fluctuations of biomass, in addition to trawl characteristics. Seasonal fluctuations in abundance were evident in the study area on the lower slope (Sardà et al., 1994). Compared with a previous study (Sardà et al., 1997), in which the lack of any seasonal effect was assumed, we found some seasonal influence on species composition after comparing MTS-25 hauls (performed between 1991 and 1995 mainly in March and April) with OTSB-14 hauls (performed in 1988-1989 mainly in June-July and October).

\section{Trawl type variability}

The main trend in the comparison of assemblage composition using different trawls was the sharp bias introduced by MTS-25 in the catches of Aristeus antennatus (i.e. $>4$ times higher than OTSB-14 catches) both at $600-750$ and at $1200-1300 \mathrm{~m}$. This positive selectivity of red shrimp by MTS-25 was also found when it was compared with 2-warp trawls, i.e. commercial hauls. It is well known that $A$. antennatus has strong interannual fluctuations in abundance, and in some years it even disappears from the fishing grounds (Maynou, 2008). Landings at the harbours of Barcelona and Vilanova were especially high in 1991-1992, whereas they decreased to normal or average catches in 1994-1995 (Maynou, 2008). Therefore, the peak of $A$. antennatus in 1994-95 using an MTS-25 trawl did not coincide with landing changes. The presumably low catches in 1992 with an OTSB-14 even coincided with a peak in landings. Thus, the differences observed were not related to fluctuations in red shrimp abundance but to the type of gear used.

On the lower slope a similar trend of higher catches with MTS-25 was found for the fish Alepocephalus rostratus, in agreement with previous analyses (Sardà et al., 1997; Moranta et al., 1998). Sampling with trawls of different opening height gives ecological information on the distribution of species close to the bottom (Engås and God $\varnothing, 1986)$. A. rostratus feeds on gelatinous plankton (medusae, pyrosomids: Carrassón and Cartes, 2002) at $1200 \mathrm{~m}$ depth, so 
its benthopelagic behaviour may favour avoidance of trawls with a low opening height like OTSB-14. This trawl opens $1.2 \mathrm{~m}$ vertically (as SCANMAR systems record) on average (cited as $2 \mathrm{~m}$ by Sardà et al., 1997). Because MTS-25 opens to $2 \mathrm{~m}$, we can conclude that most $A$. rostratus biomass occurs well above one metre from the bottom. Such biases may change the apparent bathymetric location of peaks of biomass, especially in swimming or bathypelagic animals (Merrett et al., 1991a). Gordon and Bergstad (1992) have shown that fast-swimming species (e.g. squalid sharks and alepocephalids) were more abundantly caught by a wider trawl operated at higher trawling speeds. We think estimates of A. rostratus abundance mainly depend on the opening height of trawls used.

Codend mesh size is one of the main factors explaining differences in species composition using different trawls (Merrett et al., 1991a). Despite the small $(10 \mathrm{~mm})$ mesh of the MTS-25 codend, the greatest dissimilarities were observed when MTS-25 was compared with 2-warp trawl catches. These larger differences were not found among small species, as expected, but among medium and large-sized species (e.g. sharks and macrourids). In addition, medium-sized species, such as the fish Lepidion lepidion and the shrimp Acanthephyra eximia, were caught in significantly greater numbers using an OTSB-14 than an MTS-25. This suggests that MTS-25 is selective for most species, probably because it was designed specifically for a commercial species, the red shrimp. In contrast to Alepocephalus rostratus, positive selectivity of MTS-25 for Aristeus antennatus in comparison with OTSB-14 is unrelated to swimming capacity, because i) the red shrimp diet off the Catalan coasts is mainly infauna and suprabenthos (Cartes, 1994), which are distributed at $0-1 \mathrm{~m}$ above the bottom, and ii) similar yields were obtained for A. antennatus using an OTSB-14 and 2-warp trawls (CT/ GOC73) with opening heights of ca. $3 \mathrm{~m}$. As MTS25 does not catch smaller species/specimens than commercial trawls, it probably enhances biggerdeeper trends when it is used across wide bathymetric ranges.

In terms of species richness and diversity, OTSB14 behaved better than MTS-25 at 600-750 m, with higher $S$ and $H^{\prime}$. Surprisingly, diversity of MTS-25 hauls was no greater than that of 2-warp trawls. This can also be explained by the highly positive selectivity of MTS-25 towards Aristeus antenna- tus (see Fig. 4), because the high dominance of a single species reduces $H^{\prime}$ values. Different trawls also increase artifactual variability when patterns found in different areas are compared, e.g. in studies of zonation. For example, Maynou and Cartes (2000) found differences in zonation for decapod crustaceans collected in the Algerian Basin from patterns previously found in the Catalano-Balearic Basin by Cartes and Sardà (1993); the former study was performed with MTS-25, the latter with OTSB-14. Differences mainly consisted in a lack of renewal of assemblages at around $1200 \mathrm{~m}$ off the Algerian Basin (Maynou and Cartes, 2000). Most species of decapod crustaceans are present in both the Balearic and Algerian Basins (e.g. both mainland and insular areas: Cartes et al., 2004; Massutí and Reñones, 2005). Although different food availability in the two areas explains differences in species composition, the 1200-1300 m boundary coincided in the Catalan Sea with significant changes in the population structure and biomass of Aristeus antennatus (Sardà and Cartes, 1993), and other decapods. Thus, biases introduced by differing trawl effectiveness, which are species-dependent, can affect the centres of gravity of species and the zonation patterns reported in the literature.

In conclusion, we have shown that at mid-bathyal depths off the Catalonian coasts OTSB-14 is an effective trawl for community studies, showing significantly greater abundance estimates than MTS25, CT and GOC73, and greater diversity (both $H^{\prime}$ and $S$ ) than MTS-25. The OTSB, often considered as an adequate megafaunal sampler at great depths (>1000 m) (Rucabado et al., 1991), also gave acceptable results for biomass (non-significantly lower values than MTS-25 and the two 2-warp systems) at $600-750 \mathrm{~m}$. On the lower slope seasonality influenced trawl comparisons; however, it seems reasonable to consider that MTS-25, with greater opening height than OTSB-14, was better at catching the benthopelagic fish Alepocephalus rostratus. The greater biomass obtained by MTS-25 on the lower slope is mainly attributable to this species. MTS-25 positively selected the red shrimp Aristeus antennatus, and it seemed that this positive selection was parallel to negative selection for other species of fish and decapods, giving a more biased picture of species composition than the other samplers. OTSB-14 seems to be the most suitable system for the study of some trends in deep-sea ecology, particularly regarding diversity. 


\section{ACKNOWLEDGEMENTS}

We deeply appreciate the help of all participants in all the cruises that our analyses were based upon, especially the crew of RVs Garcia del Cid and Cornide de Saavedra, aboard which these cruises were performed, and the crew of FV Stella Maris, especially its master Mr. V. Samper. This study was performed within the framework of the BIOMARE project (ref. CTM2006-13508-CO2-02/MAR), and is partially based on data generated within this project.

\section{REFERENCES}

Abelló, P. and F.J. Valladares. - 1988. Bathyal decapod crustaceans of the Catalan sea (Northwestern Mediterranean). Mésogée, 48: 97-102.

Abelló, P., F.J. Valladares and A.Castellón. - 1988. Analysis of the structure of decapod crustacean assemblages off Catalan coasts (North-West Mediterranean). Mar. Biol., 98: 39-49.

Abelló, P., A. Carbonell and P. Torres. - 2002. Biogeography of epibenthic crustaceans on the shelf and upper slope off the Iberian Peninsula Mediterranean coasts: implications for the establishment of natural management areas. Sci. Mar., 66(2): 183-198.

Anderson, M.J. - 2001. A new method for non-parametric multivariate analysis of variance. Austral Eco., 26: 32-46.

Bergstad, O.A., T. Falkenhaug, O. S. Astthorsson, I. Byrkjedal, A.V. Gebruk, U. Piatkowski, I.G. Priede, R.S. Santos, M. Vecchione, P. Lorance and J.D.M. Gordon. - 2008. Towards improved understanding of the diversity and abundance patterns of the mid-ocean ridge macro- and megafauna. Deep Sea Res. II, 55: $1-5$.

Bertrand, J.A., I. Leonori, P.Y. Dremiére and G. Cosimi. - 2002a. Depth trajectory and performance of a trawl used for an international bottom trawl survey in the Mediterranean. Sci. Mar., 66(Suppl. 2): 169-182.

Bertrand, J., L. Gil de Sola, C. Papaconstantinou, G. Relini and A. Souplet. $-2002 \mathrm{~b}$. The general specifications of the MEDITS surveys. Sci. Mar., 66(Suppl. 2): 9-17.

Carrassón, M. and J.E. Cartes. - 2002. Trophic relationships in a Mediterranean deep-sea fish community: partition of food resources, dietary overlap and connections within the Benthic Boundary Layer. Mar. Ecol. Prog. Ser., 241: 41-55.

Cartes, J.E. - 1993. Deep-sea decapod fauna of the Western Mediterranean: Bathymetric distribution and biogeographic aspects. Crustac. Int. J. Crustac. Res., 65(1): 29-40.

Cartes, J.E. - 1994. Influence of depth and season on the diet of the deep-water aristeid Aristeus antennatus along the continental -slope $(400 \mathrm{~m}$ to $2300 \mathrm{~m}$ ) in the Catalan sea (Western Mediterranean). Mar. Biol., 120: 639-648.

Cartes, J.E. - 1998. Dynamics of the bathyal Benthic Boundary Layer in the north-western Mediterranean: depth and temporal variations in macrofaunal-megafaunal communities and their possible connections within deep-sea trophic webs. Prog. Oceanogr., 41: 111-139.

Cartes, J.E. and F. Sardà. - 1993. Zonation of deep-sea decapod fauna in the Catalan Sea (Western Mediterranean). Mar. Ecol. Prog. Ser., 94: 27-34.

Cartes, J.E. and J.C. Sorbe. - 1996. Temporal population structure in deep-water cumaceans along the western Mediterranean slope (between 400 to 1300 m). Deep-sea Res., 43: 1423-1438.

Cartes, J.E., J.B. Company and F. Maynou. - 1994. Deep-water decapod crustaceans communities in the Northwestern Mediterranean: Influence of submarine canyons and season. Mar. Biol., 120: 221-230.

Cartes, J.E., P. Abelló, D. Lloris, A. Carbonell, P. Torres, F. Maynou and L. Gil de Sola. - 2002. Analysis of feeding guilds of fish and decapod crustaceans during the MEDITS-99 cruise along the Iberian Peninsula Mediterranean coasts. Sci. Mar., 66(2): 209-220.

Cartes, J.E., F. Maynou, J. Moranta, E. Massutí, D. Lloris and B. Morales-Nin. - 2004. Changes in the patterns of bathymetric distribution among deep-sea fauna at local spatial scale: comparison of mainland vs. insular areas. Prog. Oceanogr., 60(1): $29-45$.

Cartes, J.E., T. Madurell, E. Fanelli and J.L. López-Jurado. - 2008 Dynamics of suprabenthos-zooplankton communities around the Balearic Islands (NW Mediterranean): influence of environmental variables and effects on higher trophic levels. J. Mar. Syst., 71: 316-335

Clarke, K.R. and R.M. Warwick. - 1995. Changes in marine communities: an approach to statistical analysis and interpretation. Natural Environment Research Council, United Kingdom.

Engås, A. and O.R. Godø. - 1986. Influence of trawl geometry and vertical distribution of fish on sampling with bottom trawl. $J$. Northwest Atl. Fish. Sci., 7(1): 35-42.

Fanelli, E. and J.E. Cartes. - 2008. Spatio-temporal variability in the diet of two pandalid shrimps in the western Mediterranean evidenced from gut- contents and stable isotope analysis: influence on the reproductive cycle. Mar. Ecol. Prog. Ser., 355: 219-233.

Fanelli, E., F. Colloca and G. Ardizzone. - 2007. Decapod crustacean assemblages off the West coast of central Italy (Western Mediterranean). Sci. Mar., 71(1): 19-28.

Gordon, J.D.M. and J.A.R.Duncan. - 1985. The ecology of deepsea benthic and benthopelagic fish on the slopes of the Rockal Trough, Northeastern Atlantic. Prog. Oceanogr., 15: 37-69.

Gordon, J.D.M. and O.A. Bergstad. - 1992. Species composition of demersal fish in the Rockall Trough, north-eastern Atlantic, as determined by different trawls. J. mar. biol. Ass. U.K., 72: 213-230.

Haedrich, R.L., G.T. Rowe and P.T. Polloni. - 1975. Zonation and faunal composition of epibenthic populations on the continental slope south of New England. J. Mar. Res., 33(2): 191-212.

Lagardère, J.P. - 1971. Les crevettes des côtes du Maroc. Séries Zool. 36. Trav. Inst. Scient. Chérif. Fac. Sci. Rabat.

Macpherson, E. - 1981. Resource partitioning in a Mediterranean demersal fish community. Mar. Ecol. Prog. Ser. 4: 183-193.

Madurell, T. and J.E. Cartes. - 2005. Trophodynamics of a deep-sea demersal fish assemblage from the bathyal eastern Ionian Sea (Mediterranean Sea). Deep-sea Res. I., 52: 2049-2064.

Margalef, R. - 1985. Introduction to the Mediterranean. In: R. Margalef (ed.), Key Environments: Western Mediterranean. pp. 1-16. Pergamon Press Ltd., Oxford.

Massutí, E. and O. Reñones. - 2005. Demersal resource assemblages in the trawl fishing grounds off the Balearic Islands (western Mediterranean). Sci. Mar., 69: 167-181.

Maynou, F. - 2008. Environmental causes of the fluctuations of red shrimp (Aristeus antennatus) landings in the Catalan Sea. J. Mar. Syst., 71: 294-302.

Maynou, F., and J.E. Cartes. - 2000. Community structure of bathyal decapod crustaceans off south-west Balearic Islands (western Mediterranean): seasonality and regional patterns in zonation. $J$. Mar. Biol. Ass. U.K., 80: 789-798.

Merrett, N.R., J.D.M. Gordon, M. Stehman and R.L. Headrich. 1991a. Deep demersal fish assemblage structure in the Porcupine Seabight (eastern North Atlantic): slope sampling by three different trawls compared. J. Ma. Biol. Ass. U.K., 71: 329-358.

Merrett, N.R., R.L. Headrich., J.D.M. Gordon and M. Stehman. 1991b. Deep demersal fish assemblage structure in the Porcupine Seabight (eastern North Atlantic): results of single warp trawling at lower slope to abyssal soundings. J. Ma. Biol. Ass. U.K., 71: 359-373.

Moranta, J., C. Stefanescu, E. Massutí, B. Morales-Nin and D. Lloris. - 1998. Fish community structure and depth-related trends on the continental slope of the Balearic Islands (Algerian basin, western Mediterranean). Mar. Ecol. Prog. Ser., 171: 247-259.

Palanques, A., E. García-Ladona, D. Gomis, J. Martín, M. Marcos, A. Pascual, M. Emelianov, P. Puig, J. Guillén, J.M. Gili, J. Tintoré, A. Jordi, G. Basterretxea, J. Font, M. Segura, D. Blasco, S. Montserrat, S. Ruiz and F. Pagès. - 2005. A multidisciplinary program to study the dynamics and the ecology of a Northwestern Mediterranean submarine canyon: the Palamós Canyon. Prog. Oceanogr., 66: 89-119. 
Pearcy, W.G., D.L. Stein and R.S. Carney. - 1982. The deep-sea benthic fish fauna of the northwestern Pacific Ocean on Cascadian and Tufts Abyssal Plains and adjoining continental slopes. Biol. Oceanogr., 1: 375-428.

Pérès, J.M. - 1985. History of the Mediterranean biota and the colonization of depths. In: R. Margalef, (ed.). Key Environments: Western Mediterranean. pp. 198-233. Pergamon Press Ltd., Oxford.

Rucabado, J., D. Lloris and C. Stefanescu. - 1991. OTSB-14: un arte de arrastre bentónico para la pesca profunda (por debajo de los mil metros) Inf. Téc. Sci. Mar., 165: 1-27.

Sardà, F and J.E Cartes - 1993. Relationship between size and depth in decapod crustacean populations on the slope between 900 and $2200 \mathrm{~m}$ in the Western Mediterranean. Deep-Sea Res., 40(11/12): 2389-2400.

Sardà, F., J.E. Cartes and J.B. Company. - 1994. Spatio-temporal variations in megabenthos abundance on three different habitats of the Catalan deep-sea (Western Mediterranean). Mar. Biol. 120: 211-220.

Sardà, F., J.E. Cartes, J.B. Company and A. Albiol. - 1997. MS Semi-balloon trawl: an efficient system for deep-sea sampling of megabenthos. Fish. Sci. Japan, 32: 4-9.

Szalay, von, P.G. and E. Brown. - 2001. Trawl comparison of fishing power differences and their applicability to National Marine Fisheries Service and Alaska department of Fish and game trawl Survey Gear. Alaska Fish. Res. Bull., 8(2): 85-95.
Stefanescu, C., D. Lloris, J. Rucabado. - 1992. Deep-Living Demersal Fishes in the Catalan Sea (Western Mediterranean) below a Depth of 1000 m. J. Nat. Hist. 26: 197-213.

Stefanescu, C., D. Lloris and J. Rucabado. - 1993. Deep-fish assemblages in the Catalan Sea (western Mediterranean) below a depth of 1000 m. Deep-Sea Res., 40(4): 695-707.

Tyler, P.A. - 1988. Seasonality in the Deep Sea. Oceanogr. Mar. Biol. Ann. Rev., 26: 227-258.

Tyler, P.A. - 2003. Ecosystems of the Deep Ocean. Ecosystems of the World 28. Amsterdam, Elsevier.

d'Udekem d'Acoz, C. - 1999. Inventory and distribution of the decapod crustaceans from the northeastern Atlantic, the Mediterranean and the adjacent continental waters north of $25^{\circ} \mathrm{N}$. Mus. Nat. Hist. natur. Paris. Coll. Patrimoines Nat., 40: 1-383.

Vargas-Yáñez, M., F.Moya, E. Tel, M.C. García-Martínez, E. Guerber and M. Bourgeon. - 2009. Warming and salting in the western Mediterranean during the second half of the 20th century: inconsistencies, unknowns and the effect of data processing. Sci. Mar., 73(1): 7-28.

Wilderbauer, T.K., R.F. Kappenman and D.R. Gunderson. - 1998. Analysis of fishing power correction factor estimates from a trawl comparison experiment. N. Am. J. Fish. Manag., 18: 11-18.

Scient. ed.: M.P. Olivar.

Received July 3, 2008. Accepted February 10, 2009.

Published online July 13, 2009. 